\title{
Literatur zum Thema: Kleinkundenmanagement
}

\section{Literaturhinweise zusammengestellt von Diplom-Kauffrau You-Cheong Lee}

\section{Bücher}

Belz, C./Schmitz, C. (2008):

Erfolg mit kleinen Geschäften im Businessto-Business Marketing, St. Gallen.

Belz, C./Bieger, T. (2006):

Customer-Value: Kundenvorteile schaffen Unternehmensvorteile, 2. Auflage, Landsberg am Lech.

Coughlan, A./Anderson, E./Stern, L.W./

El-Ansary, A. (2006):

Marketing Channels, 7th edition, Upper Saddle River, New Jersey.

Lilien, G. L./Grewal, R. (2012):

Handbook on Business-to-Business Marketing, Northampton, MA.

Sfip ${ }^{*} S F P^{\star S c h m i t z, ~ C . / A h l e r s, ~ M . / ~ B e l z, ~ C . ~}$ (2013):

Stellhebel im Kleinkundenmanagement, in: Binckebanck, L./Hölter, A.-K./Tiffert, A. (Hrsg.): Führung von Vertriebsorganisationen, Wiesbaden, S. 171-188 (ID: 4727656).

\section{Artikel}

Aghte, I./Winkler, G. (2012):

Improving Return on Sales by Better Managing Small Customers, McKinsey \& Company.

Ahlers, M. (2012):

Wachstumspotenzial Kleinkunde, in: Acquisa, 10,9 , pp. 58-59.

Ahlers, M. (2012):

Entdecken Sie das Potenzial Ihrer Kleinkunden, in: Vertriebszeitung.de.

Anderson, C. (2008):

The long tail: Why the Future of Business Is Selling Less of More, New York.

Elberse, A. (2008):

Should You Invest in the Long Tail?, in: Harvard Business Review, 86, 7/8, pp. 88-96.

Belz, C./ Schmitz, C./ Zupancic, D. (2008): So managen Sie Kleinkunden, in: Harvard Business Manager, 30, 7, S. 70-79.

Blömeke, E./Clement, M./Bijmolt, T. H. A. (2010):

Should They Stay Or Should They Go?: Reactivation and Termination of Low-Tier
Customers: Effects on Satisfaction, Word-ofMouth, and Purchases, University of Groningen.

Bowman, D./Darayandas, D. (2004): Linking Customer Management Effort to Customer Profitability in Business Markets, in: Journal of Marketing Research, 41, 4, pp. 433-447.

Elser, B./Jung, U./Willers, Y. (2010):

Opportunities in Chemical Distribution: Optimizing Marketing and Sales Channels, Managing Complexity, and Redefining the Role of Distributors, The Boston Consulting Group, Inc.

http://www.bcg.com/documents/file37956. pdf

Haenlein, M./Kaplan, A. M./Schoder, D. (2006):

Valuing the Real Option of Abandoning Unprofitable Customers When Calculating Customer Lifetime Value, in: Journal of Marketing, 70, 3, pp. 5-20.

Haenlein, M./Kaplan, A. M. (2009):

Unprofitable Customers and Their Management, in: Business Horizons, 52, 1, pp. 89-97.

Homburg, C./Droll, M./Totzek, D. (2008): Customer Prioritization: Does It Pay Off, and How Should It Be Implemented?, in: Journal of Marketing, 72, 5, pp. 110-130.

Homburg, C./ Steiner, V. V./ Totzek, D. (2009):

Managing Dynamics in a Customer Portfolio, in: Journal of Marketing, 73, 5, pp. 70-89.

Johnson, M. W./Christensen, C. M./ Kagermann, H. (2008):

Reinventing Your Business Model, in: Harvard Business Review, 86, 12, pp. 57-68.

Johnson, M. D./Fred Selnes (2005):

Diversifying Your Customer Portfolio, in: MIT Sloan Management Review, 46, 3, pp. 11-14.

Ledingham D./Kovac M./Heric, M./Montaville, F. (2013):

Is Complexity Killing Your Sales Model?: How to Build a Repeatable, High-Return Sales Model for Business-to-Business Markets, Bain \& Company, Inc. http://bit. ly/1d6A9Am (Abruf am... )
Mittal, V./Sarkees, M./Murshed, F. (2008):

The Right Way to Manage Unprofitable Customers, in: Harvard Business Review, 86, 4, pp. 95-102.

Payne, A./Frow, P. (2005):

A Strategic Framework for Customer Relationship Management, in: Journal of Marketing, 69, 4, pp. 167-176.

Reinartz, W./Krafft, M./Hoyer, W. D. (2004):

The Customer Relationship Management Process: Its Measurement and Impact on Performance, in: Journal of Marketing Research, 41, 3, pp. 293-305.

Rosenblum, D./Tomlinson, D./Scott, L. (2003):

Bottom-Feeding for Blockbuster Businesses, in: Harvard Business Review, 81, 3, pp. 52-9.

Schmitz, C. (2012):

Management des Kleinkundensegments, Studie der Universität St.Gallen, St. Gallen.

Subramanian, U./Raju J. S./Zhang, Z. J.

(2014):

The Strategic Value of High-Cost Customers, in: Management Science, 60, 2, pp. 494-507.

Venkatesan, R./Kumar, V. (2004):

A Customer Lifetime Value Framework for Customer Selection and Resource Allocation Strategy, in: Journal of Marketing, 68, 4, pp. 106-125.

Zeithaml, V. A./Rust, R. T./Lemon, K. N. (2001):

The Customer Pyramid: Creating and Serving Profitable Customers, in: California Management Review, 43, 4, pp. 118-142.

*Abonnenten des Portals Springer für Professionals erhalten diesen Beitrag im Volltext unter www.springerprofessional.de/ID. 